DOI: $10.19195 / 0524-4544.323 .12$

\author{
TADEUSZ KOCOWSKI \\ Uniwersytet Wrocławski \\ e-mail: tadeusz.kocowski@uwr.edu.pl
}

\title{
MATEUSZ PAPLICKI
}

Uniwersytet Medyczny im. Piastów Śląskich we Wrocławiu e-mail: mateusz.paplicki@umed.wroc.pl

\section{Forma podmiotu leczniczego a świadczenia zdrowotne}

\section{Wprowadzenie}

Zdrowie, obok życia, należy bez wątpienia do podstawowych wartości egzystencjalnych człowieka. Ochrona życia i zdrowia to jedne z podstawowych praw jednostki. Dowodzą tego regulacje zawarte w przepisach Konstytucji RP, potwierdzające ten fakt i zobowiązujące władze publiczne do organizacji odpowiednich świadczeń zapewniających ich ochronę. Zgodnie z art. 35 Karty praw podstawowych Unii Europejskiej każdy ma prawo dostępu do profilaktycznej opieki zdrowotnej i do korzystania z leczenia na warunkach ustanowionych w ustawodawstwach i praktykach krajowych. Również w regulacjach zawartych w TFUE znajdujemy postanowienia wskazujące na kompetencje Unii do prowadzenia, koordynowania oraz uzupełniania działań państw członkowskich w dziedzinie ochrony i poprawy ludzkiego zdrowia.

Dla realizacji tego zadania istotne jest ustalenie, jakie podmioty realizują działalność leczniczą oraz jak kształtowana jest sytuacja odbiorcy owych świadczeń, czyli pacjenta ${ }^{1}$. Ważne jest też wyjaśnienie, jaki zespół norm prawnych reguluje sytuację pacjenta i czy obecnie jest on bardziej destynatariuszem, czy konsumen-

${ }^{1}$ Por. S. Jarosz-Żukowska, Prawo do ochrony zdrowia i dostępu do świadczeń opieki zdrowotnej, [w:] Realizacja i ochrona konstytucyjnych wolności i praw jednostki w polskim porzadku prawnym, red. M. Jabłoński, Wrocław 2014, s. 659. 
tem. Czy na jego sytuację mają wpływ zmiany organizacyjno-własnościowe podmiotów leczniczych, a także jakie zmiany w tej sytuacji wywołują rozwiązania prawne wprowadzane przez organy Unii Europejskiej, do implementacji których jako kraj członkowski jesteśmy zobowiązani? Dokonywana w artykule analiza powyższych zagadnień została przeprowadzona przy użyciu metody dogmatycznej.

\section{Ochrona zdrowia}

Współcześnie ochrona życia i zdrowia nie jest wyłącznie indywidualną sprawą jednostki. Jednostka może i powinna zapobiegać powstawaniu stanów niekorzystnych z punktu widzenia swego zdrowia, nie jest jednak w stanie sama (być może poza nielicznymi przypadkami) zapewnić sobie, a przede wszystkim sfinansować, ewentualnych koniecznych świadczeń opieki zdrowotnej wywołanych chorobami, kalectwem czy innymi zdarzeniami losowymi negatywnie wpływającymi na aktualny stan jej zdrowia. Stąd też w art. 68 Konstytucji RP wyraźnie i jednoznacznie deklaruje się, że obywatelom, niezależnie od ich sytuacji materialnej, władze publiczne zapewniają równy dostęp do świadczeń opieki zdrowotnej finansowanej ze środków publicznych, przy czym warunki i zakres udzielania świadczeń określony jest odrębną ustawą. Władze publiczne są zobowiązane do zapewnienia szczególnej opieki zdrowotnej dzieciom, kobietom ciężarnym, osobom niepełnosprawnym i osobom w podeszłym wieku. Przepisy prawa nakładają też na nie obowiązek zwalczania chorób epidemicznych oraz zapobiegania negatywnym dla zdrowia skutkom degradacji środowiska.

Z kolei w art. 76 Konstytucji RP ustrojodawca nakłada na władze publiczne obowiązek ochrony zdrowia jednostek, które to zdrowie mogłoby doznać uszczerbku wynikającego z korzystania ze zdobyczy współczesnej cywilizacji. Władze publiczne zobowiązane są do ochrony konsumentów, użytkowników i najemców przed działaniami zagrażającymi ich zdrowiu, prywatności i bezpieczeństwu oraz przed nieuczciwymi praktykami rynkowymi. Współcześnie wiele zagrożeń dla zdrowia, a niekiedy i życia, jednostek wynika z różnego rodzaju zdarzeń związanych z nieprawidłowym lub nieumiejętnym, a czasami nawet, co bulwersujące, prawidłowym posługiwaniem się niezbędnymi w życiu codziennym maszynami, aparatami czy urządzeniami. Wiele niekorzystnych dla życia i zdrowia zdarzeń wynika z działania sił przyrody i to zarówno tej ożywionej, jak i nieożywionej, powodującej występowanie nadzwyczajnych zdarzeń czy katastrof. Stąd konieczność aktywności państwa i samorządów terytorialnych w organizowaniu instytucji ochrony zdrowia i życia poprzez zapewnienie pomocy medycznej.

Obowiązujące przepisy stanowią wyraźnie, że każdy ma prawo do ochrony zdrowia. Ochrona zdrowia należy do zadań państwa, a przede wszystkim jed- 
nostek samorządu terytorialnego ${ }^{2}$. Ustawy samorządowe wyraźnie stwierdzają, iż do ich zadań, w ramach zaspokajania zbiorowych potrzeb, należą sprawy ochrony zdrowia lub promocji i ochrony zdrowia. Promocja zdrowia to, zgodnie z art. 2 ust. 1 pkt 7 Ustawy z dnia 15 kwietnia 2011 r. o działalności leczniczej ${ }^{3}$, działania umożliwiające poszczególnym osobom i społeczności zwiększenie kontroli nad czynnikami warunkującymi stan zdrowia i przez to jego poprawę, promowanie zdrowego stylu życia oraz środowiskowych i indywidualnych czynników sprzyjających zdrowiu.

Choć przepisy ustaw posługują się pojęciem „ochrona zdrowia”, nie zawierają definicji tego istotnego dla całego systemu określenia, ograniczając się do definicji cząstkowych, np. ochrony zdrowia psychicznego. Zgodnie z art. 2 Ustawy z dnia 19 sierpnia 1994 r. o ochronie zdrowia psychicznego 4 ochrona ta obejmuje realizację zadań w szczególności dotyczących:

1) promocji zdrowia psychicznego i zapobiegania zaburzeniom psychicznym;

2) zapewnienia osobom z zaburzeniami psychicznymi wielostronnej i powszechnie dostępnej opieki zdrowotnej oraz innych form opieki i pomocy, niezbędnych do życia w środowisku rodzinnym i społecznym;

3) kształtowania wobec osób z zaburzeniami psychicznymi właściwych postaw społecznych, zwłaszcza zrozumienia, tolerancji, życzliwości, a także przeciwdziałania ich dyskryminacji.

W literaturze wskazuje się, iż „ochrona zdrowia” obejmuje działania mające na celu:

1) ochronę przed chorobami poprzez zapobieganie i zwalczanie chorób zakaźnych oraz niezakaźnych o dużym wymiarze społecznym, a także innych chorób oraz niesprawności fizycznych i psychicznych w ramach systemu opieki zdrowotnej;

2) ochronę przed zagrożeniem środowiska przyrodniczego, w tym m.in. przed zagrożeniami fizycznymi (np. hałasem, wibracjami, promieniowaniem), chemicznymi (np. zanieczyszczeniem powietrza, wody, gleby, żywności) i biologicznymi (np. bakteriami, wirusami, grzybami, robakami, alergiami), w ramach systemu ochrony środowiska;

3) ochronę przed zagrożeniami wynikającymi z niektórych warunków społecznych, takich jak ubóstwo, bezrobocie, patologie społeczne;

4) wykształcenie w ramach programów polityki społecznej i edukacyjnej systemu opieki zdrowotnej, promocji zdrowia oraz pomocy społecznej ${ }^{5}$.

2 Zob. przepisy Ustawy z dnia 8 marca 1990 r. o samorządzie gminnym (tekst jedn. Dz.U. z 2001 r. Nr 142, poz. 1591); Ustawy z dnia 5 czerwca 1998 r. o samorządzie powiatowym (tekst jedn. Dz.U. z 2001 r. Nr 142, poz. 1592); Ustawy z dnia 5 czerwca 1998 r. o samorządzie wojewódzkim (tekst jedn. Dz.U. z 2001 r. Nr 142, poz. 1590).

3 Tekst jedn. Dz.U. z 2015 r. poz. 618.

${ }^{4}$ Dz.U. z 1994 r. Nr 111, poz. 535 ze zm.

5 J. Nosko, Promocja zdrowia i ochrona zdrowia jako zadania własne samorzadu terytorialnego, cz. 1, „Zdrowie Publiczne” 2000, nr 4, s. 149. 
Ochrona zdrowia oznacza więc konieczność działań prewencyjnych państwa i jednostek samorządu terytorialnego, których celem jest niedopuszczenie do występowania zdarzeń mogących zagrażać zdrowiu jednostek. Natomiast gdy zagrożenia te wystąpiły z negatywnym skutkiem dla jednostek, powinny zostać podjęte działania mające na celu ,przywrócenie stanu poprzedniego”, co oznacza możliwość uzyskania pomocy medycznej w ramach prowadzonej przez określone podmioty publiczne lub inne jednostki działalności leczniczej. Pod pojęciem „działalności leczniczej”, zgodnie z przepisami ustawy o działalności leczniczej, rozumie się udzielanie świadczeń zdrowotnych. „Świadczenie zdrowotne” to natomiast zabiegi służące zachowaniu, ratowaniu, przywracaniu lub poprawie zdrowia oraz inne działania medyczne wynikające z procesu leczenia lub odrębnych przepisów regulujących zasady ich wykonywania.

Jednostka ma prawo domagać się świadczeń medycznych związanych z ochroną życia i zdrowia od publicznej służby zdrowia. W celu ich praktycznego wykonania państwo organizuje system podmiotów zobowiązanych do podejmowania działań w tym zakresie ${ }^{6}$. Od aktywności i skuteczności starań tych podmiotów zależy, czy obywatel może być spokojny o swoje bezpieczeństwo zdrowotne. Jednostka oczekuje także na skuteczną pomoc, gdy znajduje się w sytuacji stanowiącej bezpośrednie zagrożenia jej życia lub zdrowia. Zakres tej pomocy i udzielanych obywatelowi świadczeń określają przepisy ustaw. Określają one kto, na jakiej podstawie prawnej i w jakim zakresie jest uprawniony do otrzymywania świadczeń medycznych w ramach systemu publicznej służby zdrowia.

Świadczenie tych usług przez podmioty prywatne za odrębną opłatą na jednostkowe życzenie podmiotu zainteresowanego, nie jest zaliczane do kategorii świadczeń opieki zdrowotnej finansowanych ze środków publicznych, regulowanych przepisami Ustawy z dnia 27 sierpnia 2004 r. o świadczeniach opieki zdrowotnej finansowanych ze środków publicznych ${ }^{7}$. Prawo do tego typu świadczeń, na zasadach określonych w ustawie, mają przede wszystkim osoby objęte powszechnym, obowiązkowym i dobrowolnym ubezpieczeniem zdrowotnym, a także osoby wymienione szczegółowo w art. 2 tej ustawy.

\section{Podmioty lecznicze}

Państwo i samorządy terytorialne są organizatorami podmiotów utworzonych i utrzymywanych w celu udzielania świadczeń zdrowotnych i promocji zdrowia. Świadczenia te były i są udzielane przez zakłady opieki zdrowotnej oraz przez osoby

${ }^{6}$ A. Rabiega, Ochrona życia i zdrowia ludzkiego $w$ działaniach podmiotów administrujacych w sferze opieki zdrowotnej, Warszawa 2009, s. 32.

7 Dz.U. z 2004 r. Nr 210, poz. 2135 ze zm. 
fizyczne wykonujące zawód medyczny ${ }^{8}$. Podstawową rolę w tym systemie odgrywały i odgrywają samodzielne publiczne zakłady opieki zdrowotnej (dalej: spzoz), czyli wyodrębnione organizacyjnie i prawnie zespoły osób i środków majątkowych, które są przeznaczone do udzielania świadczeń zdrowotnych finansowanych ze środków publicznych osobom ubezpieczonym oraz innym osobom uprawnionym.

Pod koniec lat osiemdziesiątych ubiegłego wieku, wskutek transformacji ustrojowej, odeszliśmy od planowej gospodarki także w służbie zdrowia. Jej ówczesne jednostki organizacyjne, określane mianem zakładów społecznych służby zdrowia $^{9}$, zgodnie z przepisami Ustawy z dnia 30 sierpnia 1991 r. o zakładach opieki zdrowotnej ${ }^{10}$, zostały zastąpione przez zakłady opieki zdrowotnej. Ta zmiana nie miała wyłącznie charakteru semantycznego. Przewidywano bowiem tworzenie publicznych i niepublicznych zakładów opieki zdrowotnej.

Mianem „publicznego zakładu opieki zdrowotnej” określano zakład opieki zdrowotnej utworzony przez: ministra lub centralny organ administracji rządowej; wojewodę; jednostkę samorządu terytorialnego; publiczną uczelnię medyczną lub publiczną uczelnię prowadzącą działalność dydaktyczną i badawczą $\mathrm{w}$ dziedzinie nauk medycznych czy Centrum Medyczne Kształcenia Podyplomowego. Za „niepubliczny zakład opieki zdrowotnej” przyjęto zakład opieki zdrowotnej utworzony przez: Kościół lub związek wyznaniowy; pracodawcę; fundację, związek zawodowy, samorząd zawodowy lub stowarzyszenie; inną krajową albo zagraniczną osobę prawną lub osobę fizyczną bądź spółkę niemającą osobowości prawnej.

Nieco inny układ podmiotów opieki zdrowotnej został ukształtowany w przepisach Ustawy z dnia 15 kwietnia 2011 r. o działalności leczniczej ${ }^{11}$. Zgodnie $\mathrm{z}$ art. 4 tego aktu prawnego podmiotami leczniczymi są: przedsiębiorcy w rozumieniu przepisów Ustawy z dnia 2 lipca 2004 r. o swobodzie działalności gospodarczej $^{12}$, we wszelkich formach przewidzianych dla wykonywania tej działalności; samodzielne publiczne zakłady opieki zdrowotnej; jednostki budżetowe, w tym państwowe jednostki budżetowe tworzone i nadzorowane przez Ministra Obrony Narodowej, ministra właściwego do spraw wewnętrznych, Ministra Sprawiedliwości lub Szefa Agencji Bezpieczeństwa Wewnętrznego, posiadające w strukturze organizacyjnej ambulatorium, ambulatorium z izbą chorych lub lekarza; instytuty badawcze; fundacje i stowarzyszenia, których celem statutowym jest wykonywanie zadań z zakresu ochrony zdrowia i których statut dopuszcza

${ }^{8}$ Działalność lecznicza lekarzy w formie jednoosobowej działalności gospodarczej jako indywidualna praktyka lekarska, a także jednoosobowa działalność gospodarcza jako indywidualna praktyka pielęgniarki nie są przedmiotem analizy, jako że — zgodnie z art. 5 ust. 3 ustawy o działalności leczniczej — wykonywanie zawodu w ramach praktyki zawodowej nie jest prowadzeniem podmiotu leczniczego.

9 Zob. przepisy Ustawy z dnia 28 października 1948 r. o zakładach społecznych służby zdrowia i planowej gospodarce w służbie zdrowia (Dz.U. Nr 55, poz. 434 ze zm.).

10 Tekst jedn. Dz.U. z 2007 r. Nr 14, poz. 89.

11 Dz.U. z 2011 r. Nr 112, poz. 654.

12 Tekst jedn. Dz.U. z 2015 r. poz. 584. 
prowadzenie działalności leczniczej; jednostki organizacyjne tych stowarzyszeń posiadające osobowość prawną; osoby prawne i jednostki organizacyjne działające na podstawie przepisów o stosunku państwa do Kościoła katolickiego w Rzeczypospolitej Polskiej, o stosunku państwa do innych Kościołów i związków wyznaniowych oraz o gwarancjach wolności sumienia i wyznania; jednostki wojskowe - w zakresie, w jakim wykonują działalność leczniczą.

Przyjęty podział starał się uwzględnić fakt, że w art. 16 ustawy uznano działalność leczniczą za działalność gospodarczą — regulowaną w rozumieniu przepisów ustawy o swobodzie działalności gospodarczej, choć nie wszystkie podmioty mogą ten typ działalności wykonywać. Działalności regulowanej nie stanowi działalność lecznicza: podmiotów leczniczych w formie jednostki budżetowej oraz podmiotów leczniczych $\mathrm{w}$ formie jednostki wojskowej, która jest wykonywana jako działalność pożytku publicznego w rozumieniu Ustawy z dnia 24 kwietnia 2003 r. o działalności pożytku publicznego i o wolontariacie ${ }^{13}$, chyba że zachodzą przesłanki określone w art. 9 ust. 1 tej ustawy, a także działalność charytatywno -opiekuńcza, jeżeli odrębne przepisy przewidują prowadzenie takiej działalności.

Działalności gospodarczej nie wykonują także spzoz, jako że ustawa wyraźnie wyłącza je z kręgu przedsiębiorców. Istniały wątpliwości związane z tym, czy spzoz mają osobowość prawną, choć nie wątpiono w ich zdolność sądową i procesową oraz zdolność kierownika do wydawania generalnych aktów wewnętrznych ${ }^{14}$. Starano się zatem doprowadzić do tego, by spzoz nie był dominującą formą prowadzenia działalności polegającej na udzielaniu świadczeń zdrowotnych. Ustawodawca zdawał się bowiem traktować formę spzoz jako ograniczoną temporalnie, a w przepisach ustawy brakowało prawnych możliwości tworzenia przez publiczne organy administracji samodzielnych spzoz, z wyjątkiem przepisów dotyczących reorganizacji (przekształcenie, dzielenie, łączenie).

Przepisy ustawy o działalności leczniczej uwolniły organy założycielskie od współodpowiedzialności za działalność tych jednostek i zapewniania ciągłości udzielania świadczeń medycznych. Stwierdzały one, że spzoz z posiadanych środków i uzyskiwanych przychodów pokrywa koszty działalności i reguluje zobowiązania oraz że pokrywa we własnym zakresie ujemny wynik finansowy. Artykuł 59 przewidywał wszakże możliwość, by podmiot tworzący spzoz, w terminie 3 miesięcy od zatwierdzenia sprawozdania finansowego spzoz, mógł pokryć ujemny wynik finansowy za rok obrotowy tego zakładu, jeżeli wynik ten, po dodaniu kosztów amortyzacji, ma wartość ujemną — do wysokości tej wartości. Natomiast w przypadku niepokrycia tego ujemnego wyniku finansowego podmiot tworzący spzoz, w ciagu 12 miesięcy od upływu terminu określonego w ustawie, wydaje rozporządzenie, zarządzenie albo podejmuje uchwałę o zmianie formy organizacyjno-prawnej lub o likwidacji spzoz.

13 Dz.U. z 2014 r. poz. 1118 ze zm.

14 Por. M. Dercz, T. Rek, Ustawa o działalności leczniczej. Komentarz, Warszawa 2012, s. 71. 
Powstałe przeważnie w okresie obowiązywania ustawy z 1991 r. spzoz (osoby prawne typu fundacyjnego) w wypadku nierentowności, zgodnie z art. 59 ustawy, mogły zostać przekształcone w spółki kapitałowe. Mimo że forma prawna spzoz nie pozwala na prywatyzację tego typu jednostki (możliwa jest jedynie prywatyzacja jego majątku), możliwa była prywatyzacja spółki kapitałowej. Zbycie całości majątku spzoz jest równoznaczne z koniecznością dokonania jego likwidacji.

Z kolei art. 69 ustawy stanowi, iż przekształcenie spzoz w spółkę kapitałową odbywa się na zasadach określonych w art. 70-82 ustawy. Organ przekształcający, biorąc pod uwagę niekorzystny wynik finansowy, sporządza akt przekształcenia, który zastępuje czynności określone w przepisach Ustawy z dnia 15 września 2000 r. - Kodeks spółek handlowych ${ }^{15}$. Niezwłocznie po sporządzeniu aktu przekształcenia zarząd spółki kapitałowej składa wniosek o wpisanie spółki do rejestru przedsiębiorców, a po uzyskaniu wpisu do rejestru przedsiębiorców — wniosek o zmianę wpisu w rejestrze podmiotów wykonujących działalność leczniczą.

Ten fakt oraz przewidziana możliwość, aby Skarb Państwa i jednostki samorządu terytorialnego mogły przystępować do spółki kapitałowej wykonującej działalność leczniczą, świadczą jednoznacznie o tym, iż ustawodawca dopuszczał ewentualność prowadzenia działalności komercyjnej w ochronie zdrowia.

Sam proces prywatyzacji podmiotu związany jest $\mathrm{z}$ udostępnieniem udziałów lub akcji osobom trzecim. Spółki podlegają rygorom prawa upadłościowego i naprawczego. To dodatkowo osłabia pozycję organów administracji publicznej, pozbawiając Skarb Państwa i jednostki samorządu terytorialnego pełnej kontroli nad działalnością tych podmiotów. Traci bowiem na znaczeniu regulacja, dla której zostały one pierwotnie utworzone, czyli zaspokajanie potrzeb społeczności lokalnej w zakresie ochrony zdrowia ${ }^{16}$.

Usługi lecznicze - bardzo wolno, ale nieuchronnie — poddawane będą procesom konkurencji. Termin „konkurencja” w języku polskim, obok innych możliwych znaczeń, rozumiany jest jako współzawodnictwo, rywalizacja ${ }^{17}$. Konkurencja ta powinna doprowadzić do sytuacji, kiedy owo współzawodnictwo czy rywalizacja między zainteresowanymi podmiotami odbywać się będzie w interesie pacjenta, czyli w celu zagwarantowania mu równych praw w dostępie do świadczeń zdrowotnych odpowiadających wymaganiom aktualnej wiedzy medycznej. Zapewnienie konkurencji nie jest jednak celem samym w sobie - stanowi ona narzędzie do zwiększenia efektywności systemu ochrony zdrowia i skłonienia do racjonalnego korzystania ze świadczen ${ }^{18}$. Prywatyzacja jest więc konsekwencją niezaspokajanych potrzeb zdrowotnych pacjentów. Jest drogą, choć nie jedyną,

15 Dz.U. z 2013 r. poz. 1030 ze zm.

16 Por. M. Pawłowska, Działalność lecznicza, [w:] Materialne prawo administracyjne, red. M. Miemiec, Warszawa 2013, s. 126-127.

17 Popularny stownik języka polskiego, red. B. Dunaj, Warszawa 1999, s. 238.

18 B. Więckowska, Konkurencja między płatnikami w bazowym systemie zabezpieczenia zdrowotnego, Warszawa 2010, s. 57. 
ponieważ prywatne podmioty także nie gwarantują automatycznego polepszenia poziomu usług medycznych. Dla ograniczenia ryzyka związanego z dominacją podmiotów prywatnych nad ich świadczeniobiorcami — pacjentami, wydaje się niezbędne utrzymanie roli państwa jako regulatora opieki zdrowotnej ${ }^{19}$.

Utrudniony dostęp do świadczeń medycznych oraz ich niski poziom sprzyja rozwojowi prywatnej opieki zdrowotnej, na którą wydajemy już ok. 24 mld zł rocznie ${ }^{20}$. Kwoty tych wydatków będą rosły z roku na rok, co wnika z bogacenia się społeczeństwa ${ }^{21}$, wzrostu świadomości wspomnianych potrzeb zdrowotnych czy też problemów demograficznych, z jakimi w niedalekiej przyszłości przyjdzie nam się zmierzyć.

Skoro więc przewidywany jest wzrost środków w systemie ochrony zdrowia, $\mathrm{w}$ interesie pacjenta jest, aby przyczyniły się one do poprawy jego dobrostanu zdrowotnego, a nie były tylko księgowane jako zyski firm medycznych. Jedną z dróg zwiększenia efektywności wydatkowania środków publicznych jest wprowadzenie konkurencji między płatnikami ${ }^{22}$. Pod tym rozumie się konkurencję o uczestnika sytemu (pacjenta), którego decyzja o wyborze danego płatnika pociąga za sobą korzyść finansową w postaci określonego wkładu pieniężnego, mogącego przybrać formę dotacji, składki czy podatku²3.

W Polsce funkcje płatnika pełni Narodowy Fundusz Zdrowia (NFZ) ${ }^{24}$, który poprzez zawieranie umów na świadczenia usług zdrowotnych z konkretnymi podmiotami ochrony zdrowia przekazuje środki budżetowe przeznaczone na działanie systemu opieki zdrowotnej. NFZ jako monopolista pełni jedynie funkcję nabywcy usług w imieniu pacjentów, przy szczątkowej wiedzy o cenach i kosztach ${ }^{25}$. Brak konkurencji po stronie płatnika działa na niekorzyść pacjenta; płatnik nie jest zobowiązany do spełnienia świadczenia ubezpieczeniowego w określonym terminie oraz nie ponosi odpowiedzialności wobec pacjenta za jakość kontraktowanych świadczeń ${ }^{26}$.

Ministerstwo Zdrowia rozważa likwidację NFZ w najbliższym czasie oraz przeniesienie zadań NFZ na administrację Urzędów Wojewódzkich. Planuje się również wprowadzenie zmian $\mathrm{w}$ systemie ochrony zdrowia, mających przefor-

19 A. Hnatyszyn-Dzikowska, Konkurencja między ptatnikami w opiece zdrowotnej. Ujęcie teoretyczne, „Ekonomia i Prawo” 12, 2013, nr 2, s. 295.

${ }^{20}$ Lewiatan, Jak efektywnie inwestować publiczne pieniadze?, Warszawa 2015, s. 3, http:// konfederacjalewiatan.p1/legislacja/wydawnictwa/_files/publikacje/2015/jak_efektywnie_inwestowac_3_.pdf (dostęp: 10.11.2017).

${ }^{21}$ Ibidem.

22 J. Rutecka, B. Więckowska, Rynkowa polityka społeczna, [w:] Innowacyjna polityka spoteczna, red. M. Grewiński, A. Karwacki, Warszawa 2015, s. 138.

23 B. Więckowska, op. cit., s. 9.

24 Działający na podstawie Ustawy z dnia 27 sierpnia 2004 r. o świadczeniach opieki zdrowotnej finansowanych ze środków publicznych (Dz.U. z 2004 r. Nr 210, poz. 2135 ze zm.).

25 A. Hnatyszyn-Dzikowska, op. cit., s. 294.

26 B. Więckowska, op. cit., s. 62. 
mułować charakter systemu z ubezpieczeniowego na budżetowy. Jeżeli ostatnie $\mathrm{z}$ tych propozycji będą wiązały się z równoczesnym wzrostem wydatków na ochronę zdrowia, będą korzystne dla pacjentów. Wydaje się jednak, że sama likwidacja NFZ będzie neutralna dla pacjenta, chyba że nieprzygotowane do takich obowiązków (dystrybucji środków) Urzędy Wojewódzkie nie będą w stanie na czas zakontraktować wystarczającej liczby świadczeń zdrowotnych, co może stworzyć sytuacje zagrażające życiu i zdrowiu pacjentów.

\section{Pacjent}

Osobę zwracającą się o udzielenie świadczeń zdrowotnych lub korzystającą ze świadczeń zdrowotnych oferowanych przez podmiot udzielający świadczeń zdrowotnych lub osobe wykonująca zawód medyczny art. 3 Ustawy z dnia 6 listopada 2008 r. o prawach pacjenta i Rzeczniku Praw Pacjenta ${ }^{27}$ określają mianem pacjenta. Natomiast Światowa Organizacja Zdrowia mianem tym nazywa osobę korzystającą ze świadczeń opieki zdrowotnej, niezależnie od tego, czy jest zdrowa, czy chora. Oznacza to, iż pacjent jest użytkownikiem świadczeń zdrowotnych udzielanych przez podmiot wykonujący działalność leczniczą. Nie ulega wątpliwości, iż to on powinien być najważniejszym podmiotem analizowanego systemu.

Jeszcze stosunkowo niedawno większość usług medycznych była świadczona przez państwową służbę zdrowia, której działania w niewielkim zakresie uzupełniały tylko spółdzielnie i praktyki prywatne. Wykonywanie tych usług związane jest $\mathrm{w}$ wielu wypadkach $\mathrm{z}$ koniecznością dłuższego przebywania na terenie tych jednostek i poddania się procedurom ingerującym $\mathrm{w}$ sferę spraw intymnych o charakterze osobistym. Ich zastosowanie jest związane z koniecznością czasowego wyłączenia się danej osoby ze sfery aktywnego życia społecznego i rodzinnego oraz nieuchronną adaptacją do nowych specyficznych warunków. Wzmaga to dodatkowo, i tak niewątpliwie duży, stres wynikający z troski o zagrożone życie i zdrowie.

Stosunek, jaki istniał pomiędzy pacjentem a publicznym podmiotem leczniczym, można było określić w kategorii stosunku administracyjnoprawnego. Publiczny podmiot leczniczy kwalifikowany był jako zakład administracyjny, realizujący określony, zlecony jej zestaw zadań publicznych, przede wszystkim w sferze usług niematerialnych, mających szczególne znaczenie społeczne ${ }^{28}$, a za takie były i są uznawane usługi w ochronie zdrowia. Przy realizacji tych zadań zakłady administracyjne mają prawo do korzystania z władztwa administracyjnego, zakładowego.

27 Tekst jedn. Dz.U. z 2012 r. poz. 159.

28 Por. J. Zimmermann, Prawo administracyjne, Kraków 2005, s. 134. 
Świadczeniobiorca (pacjent — użytkownik świadczeń tego zakładu, określany mianem destynatariusza) jest więc podmiotem, w stosunku do którego ma zastosowanie władztwo zakładowe realizowane przez organy zakładu. Oczywiście zakres tego władztwa może być większy lub mniejszy, gdyż może on obejmować uprawnienie do stanowienia norm ogólnych (abstrakcyjnych) i norm indywidualnych lub jedynie indywidualnych ${ }^{29}$. Jest to zatem możliwość jednostronnego kształtowania praw i obowiązków użytkownika świadczeń i użycia przymusu w celu wyegzekwowania tych obowiązków ${ }^{30}$. Zdarza się, że zakres władztwa rozciąga się także na osoby będące na terenie zakładu, lecz niebędące destynatariuszami.

Władztwo, z którym mamy do czynienia w przypadku podmiotów leczniczych, dzieli się na dwa rodzaje. Pierwszy dotyczy kwestii związanych z funkcjonowaniem zakładu, jego organizacją i techniką świadczenia usług, a jego realizacja leży w kompetencjach organów danej jednostki. Drugi, określany mianem władztwa fachowego, związany jest z merytoryczną istotą świadczonych usług i służy pracownikom zakładu, którzy przy jego realizacji wykorzystują swą wiedzę fachową - lekarz wobec pacjenta w procesie leczenia ${ }^{31}$.

Układ ten ma znaczenie dla ukształtowania sytuacji pacjenta w zakresie możliwości dostępu do świadczeń medycznych i dla sposobów ich udzielania, a więc tego, co nazywamy prawami pacjenta. Określane są one przez akty prawne, począwszy od Konstytucji, a na porządkowych przepisach wewnętrznych podmiotów leczniczych kończąc. Ostatnio regulacja tych praw następuje w aktach coraz wyższej rangi. Doczekaliśmy się także ich regulacji w przepisach wspominanej już ustawy o prawach pacjenta. Zgodnie z art. 2 tej ustawy przestrzeganie zdefiniowanych $w$ niej praw pacjenta jest obowiązkiem organów władzy publicznej właściwych w zakresie ochrony zdrowia, Narodowego Funduszu Zdrowia, podmiotów udzielających świadczeń zdrowotnych, osób wykonujących zawód medyczny oraz innych osób uczestniczących w udzielaniu świadczeń zdrowotnych.

Przepisy ustawy stwierdzają jednoznacznie, iż pacjent ma prawo do świadczeń zdrowotnych odpowiadających wymaganiom aktualnej wiedzy medycznej. W szczególności pacjent ma prawo do:

1) natychmiastowego udzielenia świadczeń zdrowotnych ze względu na zagrożenie zdrowia lub życia;

2) przejrzystej, obiektywnej, opartej na kryteriach medycznych procedury ustalającej kolejność dostępu do tych świadczeń, w ograniczonych możliwościach udzielenia odpowiednich świadczeń zdrowotnych;

3) informacji o swoim stanie zdrowia oraz tajemnicy informacji z nim związanych;

29 Por. E. Ochendowski, Prawo administracyjne. Czesść ogólna, Torun 2000, s. 231.

30 Por. J. Boć, [w:] Prawo administracyjne, red. J. Boć, Wrocław 2010, s. 167 n.

31 Por. J. Zimmermann, op. cit., s. 135-136. 
4) dostępu do dokumentacji medycznej dotyczącej jego stanu zdrowia oraz udzielonych mu świadczeń zdrowotnych;

5) wyrażenia zgody na udzielenie świadczeń zdrowotnych albo odmowy takiej zgody po uzyskaniu odpowiedniej informacji;

6) zgłoszenia sprzeciwu wobec opinii albo orzeczenia lekarza;

7) poszanowania intymności i godności, w szczególności w czasie udzielania mu świadczeń zdrowotnych.

Prawa pacjenta niewątpliwie są istotnym elementem kształtowania jego pozycji jako użytkownika świadczeń. Specyfika tego typu świadczeń i struktura podmiotów je udzielających przez długi czas powodowała ograniczenie swobodnego decydowania przez pacjenta co do możliwości wyboru podmiotu udzielającego świadczeń. Złamanie faktycznego monopolu podmiotów publicznych zmieniło nieco tę sytuację. W ograniczonym zakresie pojawiła się na rynku krajowym konkurencja podmiotów niepublicznych posiadających status przedsiębiorców. To z kolei stworzyło następny problem - związany z tym, czy rzeczywiście usługi tego typu, w szczególności usługi o charakterze szpitalnym, powinny być świadczone przez podmioty o statusie przedsiębiorcy. Przedsiębiorca to bowiem podmiot, którego działalność nastawiona jest na zysk, co rodzi pytanie o sensowność tej konstrukcji, w szczególności przy świadczeniu usług szpitalnych. Być może warto byłoby rozważyć stosowane w niektórych krajach rozwiązanie, w którym właścicielami takich jednostek, obok samorządowych wspólnot lokalnych, są prywatne fundacje czy organizacje charytatywne. To one powinny prowadzić szpitale, właśnie po to, by realizować misję, a nie wyłącznie dążyć do osiągnięcia zysku. Zysk natomiast, o ile uda się go wypracować, powinien zostać w całości przeznaczony na potrzeby szpitala.

Ostatnio daje się również zauważyć osłabianie wyłącznie administracyjnoprawnego regulowania sytuacji prawnej pacjenta na rzecz wprowadzania rozwiązań prywatnoprawnych (umownych). Proces ten nie jest jednakże wolny od pewnych kontrowersji ${ }^{32}$ i wymaga w tym zakresie jednoznacznych regulacji. Pacjent, pozostając bowiem w pewnym sensie destynatariuszem, staje się też konsumentem ${ }^{33}$. Umowa zaczyna być więc środkiem regulującym status pacjenta, ale czy oznacza to automatyczne polepszenie jego sytuacji? Wydaje się to wątpliwe. Ponadto na jego pozycję coraz częściej wpływają pewne rozwiązania europejskie, które stają się przedmiotem implementacji do naszych rozwiązań krajowych, co zdaje się — przynajmniej formalnie — pozytywnie oddziałuje na jego sytuację.

32 E. Łętowska, Pacjent staje się konsumentem ustug medycznych, „Rzeczpospolita” 25.11.1998, http://archiwum.rp.pl/artykul/202296-Pacjent-staje-sie-konsumentem-uslug-medycznych.html (dostęp: 10.11.2017).

${ }^{33}$ Zgodnie z art. $22^{1}$ Kodeksu cywilnego ,za konsumenta uważa się osobę fizyczną dokonującą z przedsiębiorcą czynności prawnej niezwiązanej bezpośrednio z jej działalnością gospodarczą lub zawodową". 


\section{Dyrektywa transgraniczna}

Przystąpienie Polski do Unii Europejskiej spowodowało także określone zmiany w ochronie zdrowia. Jako kraj członkowski jesteśmy zobowiązani respektować kompetencje organów Unii do regulacji spraw dotyczących ochrony i poprawy zdrowia ludzkiego. Jednym z takich aktów jest Dyrektywa Parlamentu Europejskiego i Rady 2011/24/UE z dnia 9 marca 2011 r. w sprawie stosowania praw pacjentów w transgranicznej opiece zdrowotnej. Przypomniano w niej, iż państwa członkowskie ponoszą odpowiedzialność za świadczenie obywatelom na swoim terytorium bezpiecznej, wydajnej, wysokiej jakości i ilościowo odpowiedniej opieki zdrowotnej, wskazując, że skutkiem transpozycji niniejszej dyrektywy do prawa krajowego nie powinno być zachęcanie pacjentów do korzystania z leczenia poza ich państwem. Wskazano wszakże, iż celem dyrektywy jest ustanowienie zasad ułatwiających dostęp w Unii do bezpiecznej transgranicznej opieki zdrowotnej wysokiej jakości.

Wprowadzane w niej rozwiązania powinny mieć zastosowanie do poszczególnych pacjentów, którzy decydują się skorzystać z opieki zdrowotnej w innym państwie członkowskim niż państwo członkowskie ubezpieczenia. W dyrektywie przewidziano jednak, iż państwo członkowskie ubezpieczenia może postanowić, że ograniczy zwrot kosztów transgranicznej opieki zdrowotnej z powodów związanych z jakością i bezpieczeństwem świadczonej opieki zdrowotnej, gdy jest to uzasadnione nadrzędnymi względami, podyktowanymi interesem ogólnym dotyczącym zdrowia publicznego. Mimo wszystko głównym założeniem dyrektywy było zapewnienie realizacji zasady swobody przepływu usług na terytorium Unii Europejskiej w sferze opieki zdrowotnej — zgodnie z dorobkiem orzeczniczym Trybunału Sprawiedliwości UE - tj. stworzenie przejrzystych ram prawnych w zakresie korzystania ze świadczeń zdrowotnych w innych państwach członkowskich UE, z możliwością uzyskania przez każdego pacjenta zwrotu kosztów takich świadczeń od publicznego systemu ubezpieczenia zdrowotnego, któremu podlega.

Dyrektywa została zaimplementowana do polskiego porządku prawnego poprzez nowelizację przepisów Ustawy z dnia 27 sierpnia 2004 r. o świadczeniach opieki zdrowotnej finansowanych ze środków publicznych ${ }^{34}$. Do jej przepisów wprowadzono rozdział 2a, zatytułowany „Świadczenia opieki zdrowotnej udzielone poza granicami kraju". Zamieszczony w nim art. 42a przewiduje, iż Narodowy Fundusz Zdrowia finansuje koszty świadczeń opieki zdrowotnej udzielonych poza granicami kraju: na zasadzie zwrotu kosztów, o którym mowa w art. 42b ustawy; zgodnie z przepisami o koordynacji; a także na podstawie decyzji dyrektora oddziału wojewódzkiego Funduszu. Przepisy ustawy szczegółowo regulują problematykę zwrotu kosztów świadczenia opieki zdrowotnej, będącego świad-

34 Dz.U. z 2004 r. Nr 210, poz. 2135 ze zm. 
czeniem gwarantowanym, udzielonego na terytorium innego niż Rzeczpospolita Polska państwa członkowskiego Unii Europejskiej, w szczególności zaś obliczanie wysokości tej kwoty.

Uwzględniając, że jednym z założeń Unii jest swoboda jej obywateli w zakresie przemieszczania się i przebywania na terytorium państw członkowskich, regulacje te stają się niezbędne i to niezależnie od aktualnie dokonywanych ocen wynikających z ograniczoności środków finansowych przeznaczonych na opiekę zdrowotną. Należy zauważyć, iż zmiany te pozwalają również polskim podmiotom leczniczym na swobodniejsze pozyskiwanie pacjentów z innych państw członkowskich.

\section{Zmiany w systemie z lat 2016-2017}

Dokonana w 2016 r. nowelizacja ustawy o działalności leczniczej ${ }^{35}$ spowodowała zmiany w dotychczasowej sytuacji prawnej spzoz. Artykuł 50 uregulował sporny problem możliwości tworzenia spzoz. Ustalono, iż obecnie utworzenie spzoz następuje w drodze rozporządzenia, zarządzenia albo uchwały właściwego organu podmiotu tworzącego. Tworząc spzoz, uwzględnia się także konieczność zapewnienia bezpieczeństwa zdrowotnego obywateli oraz racjonalnej organizacji opieki zdrowotnej. Akt inicjujący powstanie spzoz powinien zawierać: nazwę i siedzibę samodzielnego publicznego zakładu opieki zdrowotnej; określenie rodzaju działalności leczniczej oraz określenie mienia, w które wyposaża się samodzielny publiczny zakład opieki zdrowotnej. Z chwilą wpisania do Krajowego Rejestru Sądowego spzoz uzyskuje osobowość prawną.

Istotną zmianą jest również wyłączenie $\mathrm{z}$ treści dotychczasowego art. 59 ustawy możliwości podjęcia przez podmiot tworzący spzoz decyzji o zmianie formy organizacyjno-prawnej spzoz w przypadku niepokrycia ujemnego wyniku finansowego w sposób określony w ustawie, co skutkowało przekształceniem spzoz w spółkę kapitałową. Przekształcenie w wielu wypadkach stanowiło bowiem pierwszy etap prywatyzacji podmiotów medycznych.

Postanowiono ponadto, że w spółce kapitałowej prowadzącej działalność podmiotu leczniczego, tworzonej przez Skarb Państwa lub jednostki samorządu terytorialnego, lub do której podmioty te przystąpiły, wartość nominalna udziałów bądź akcji należących do Skarbu Państwa lub jednostki samorządu terytorialnego nie może stanowić mniej niż 51\% kapitału zakładowego spółki, a Skarb Państwa albo jednostka samorządu terytorialnego muszą dysponować bezpośrednio większością głosów na zgromadzeniu wspólników lub na walnym zgromadzeniu.

35 Zob. przepisy Ustawy z dnia 10 czerwca 2016 r. o zmianie ustawy o działalności leczniczej oraz niektórych innych ustaw (Dz.U. z 2016 r. poz. 960). 
Przepis ten ma zastosowanie także do już funkcjonujących spółek kapitałowych prowadzących działalność leczniczą z udziałem Skarbu Państwa lub jednostek samorządu terytorialnego oraz uczelni medycznych, w których podmioty te obecnie posiadają udziały lub akcje o wartości nominalnej nie mniejszej niż 51\% kapitału zakładowego spółki. Ma to na powrót wzmocnić współodpowiedzialność organów założycielskich za działalność spzoz.

Działania, które niewątpliwie osłabią konkurencję i mogą spowolnić proces przekształceń własnościowych w służbie zdrowia, to wprowadzanie systemu podstawowego szpitalnego zabezpieczenia świadczeń opieki zdrowotnej, zwanego dalej „systemem zabezpieczenia"36. Przed wprowadzeniem systemu w okresowych postępowaniach konkursowych mogli brać udział wszyscy świadczeniodawcy spełniający warunki określone w ustawie oraz odpowiednich rozporządzeniach wykonawczych. Wprowadzona nowelizacja doprowadzi do tego, że zawieranie umów na realizację świadczeń w zakresie leczenia szpitalnego w trybie konkursu ofert lub rokowań zostanie rozwiązaniem tylko o charakterze subsydiarnym ${ }^{37}$.

Stworzenie tzw. sieci szpitali, według Ministerstwa Zdrowia, ma z założenia usprawnić organizację udzielania świadczeń opieki zdrowotnej przez szpitale oraz przychodnie przyszpitalne i poprawić dostęp pacjentów do leczenia specjalistycznego w szpitalach. Taka sieć pozwoli ponadto zoptymalizować liczbę oddziałów specjalistycznych i umożliwi lepszą koordynację świadczeń szpitalnych i ambulatoryjnych oraz zarządzanie szpitalami ${ }^{38}$.

\section{Zakończenie}

Zmiany dokonywane w organizacji służby zdrowia, i to zarówno te wynikające $\mathrm{z}$ inicjatywy wewnętrznej, jak i te implementowane, niewątpliwie wprowadzają nową jakość do istniejącego systemu. Idzie bowiem o to, by cały system stał się bardziej przyjazny dla podstawowego użytkownika jego świadczeń, jakim jest pacjent. W tej dziedzinie uczyniono już wiele, ale także wiele pozostaje $\mathrm{w}$ tej materii do zrobienia. Przyjmowane rozwiązania niestety nie tworzą jednolitego

36 Według art. $95^{1}$ ust. 1 Ustawy z dnia 23 marca 2017 r. o zmianie ustawy o świadczeniach opieki zdrowotnej finansowanych ze środków publicznych (Dz.U. z 2017 r. poz. 844) ma on być główną formą zabezpieczenia dostępu do świadczeń opieki zdrowotnej w zakresie: leczenia szpitalnego, świadczeń wysokospecjalistycznych, ambulatoryjnej opieki specjalistycznej realizowanej w poradniach przyszpitalnych, rehabilitacji leczniczej, programów lekowych, leków stosowanych w chemioterapii oraz nocnej i świątecznej opieki zdrowotnej, przy jednoczesnym zagwarantowaniu ciągłości i kompleksowości udzielanych świadczeń oraz stabilności ich finansowania.

37 Uzasadnienie rządowego projektu ustawy o zmianie ustawy o świadczeniach opieki zdrowotnej finansowanych ze środków publicznych, druk 1322, Warszawa 2017, s. 4, http://www.sejm. gov.pl/Sejm8.nsf/druk.xsp?nr=1322 (dostęp: 10.11.2017).

38 Ibidem, s. 3 n. 
ramowego programu z jasno określonym celem, co powoduje dużą niepewność co do kształtu ostatecznych rozwiązań w tej dziedzinie. Powinniśmy wszakże pamiętać, że osią systemu pozostaje pacjent i to jego dobro powinno w jak największym stopniu przyświecać przyjmowanym rozwiązaniom.

\section{Form of medical entity and medical services}

\section{Summary}

Health undoubtedly belongs of the fundamental existential values for human. Current legal regulations state that everyone is entitled to health care. Health care is a government task, executed especially by local government units.

An individual has the right to claim medical services related to the protection of life and health from the public health service. For their practical implementation, government establishes a system of entities obliged to take action in this field. Unfortunately, the actions taken do not create a unified system in which the patient and his health are the most important value.

Keywords: medical services, medical entity, health care, patient's rights, medical law. 